\title{
Lipid Levels and Disorders in Hospital Attendants in Banjul, The Gambia
}

\author{
Bernard C. Nkum¹, Frank B. Micah1, Theophilus C. Ankrah"1, Ousman A. Nyan²,3 \\ ${ }^{1}$ Department of Medicine, School of Medical Sciences, Kwame Nkrumah University of Science and Technology, \\ Kumasi, Ghana \\ ${ }^{2}$ Department of Medicine \& Therapeutics, Edward Francis Small Teaching Hospital, School of Medicine \& Allied \\ Health Sciences, University of The Gambia, Banjul, The Gambia \\ ${ }^{3}$ Medical Research Council Laboratories, Fajara, The Gambia \\ Email: bcnkum10@yahoo.co.uk,fbmicah@hotmail.com, theo_ankrah@yahoo.com, onyan@utg.edu.gm
}

Received 18 February 2016; accepted 3 March 2016; published 7 March 2016

Copyright (C) 2016 by authors and OALib.

This work is licensed under the Creative Commons Attribution International License (CC BY).

http://creativecommons.org/licenses/by/4.0/

(c) (i) Open Access

\begin{abstract}
Background: One of the major risk factors for cardiovascular diseases is lipid abnormalities. Objective: To determine the mean lipid levels and the prevalence of lipid disorders among patients attending outpatient clinics in Banjul, The Gambia. Design: Cross-sectional study. Setting: Outpatient clinics of Royal Edward Francis Small Teaching Hospital and Medical Research Council Laboratories in Banjul, The Gambia. Methods: Two hundred and eight consecutive patients with systemic hypertension on treatment and 108 non-hypertensive patients aged over 25 years were enrolled. A questionnaire was filled and anthropometric measurements were taken. An oral glucose tolerance test (OGTT) was done as well as blood investigations including total cholesterol (TC), high-density lipoprotein cholesterol (HDL) and triglycerides (TG). Low-density lipoprotein cholesterol (LDL) was calculated using the Friedwald formula. There were 305 participants with complete lipid results and these were included in the analysis. Results: The mean (standard deviation) TC was $4.92(1.78) \mathrm{mmol} / \mathrm{L}$; mean TG was $0.94(0.56) \mathrm{mmol} / \mathrm{L}$; mean HDL was $1.28(0.48)$ mmol/L and mean LDL was 3.20 (1.41) $\mathrm{mmol} / \mathrm{L}$. The prevalence of lipid abnormalities was $41 \%$ for high TC, $9 \%$ for high TG, $36 \%$ for low HDL, $49 \%$ for high LDL and $6 \%$ for atherogenic dyslipidaemia. Conclusion: The mean lipid level and the prevalence of lipid disorders in patients attending clinics in Banjul were high.
\end{abstract}

\section{Keywords}

Lipids, Lipid Disorders, Atherogenic Dyslipidaemia, Systemic Hypertension, Diabetes Mellitus

Subject Areas: Internal Medicine 


\section{Introduction}

Lipid disorders are now established as major risk factors for cardiovascular diseases (CVD) such as coronary artery disease, stroke and peripheral vascular disease [1]. These abnormalities of lipids cause CVD through the promotion of atherosclerosis, where there is increased deposition of cholesterol in the blood vessel wall, resulting in narrowing of the lumen of the vessel and hardening of the vessel wall. High levels of LDL lead to increased deposition of cholesterol in arterial walls while high levels of HDL reduce the risk of CVD [1]. The role of hypertriglyceridaemia remains controversial though there is indirect evidence from studies which have shown its association with coronary artery disease [2] [3]. Lipid disorders are more common in patients with diabetes mellitus (DM) and systemic hypertension (HPT) than in the general population and the progression of atherosclerosis is more rapid in these patients resulting in an increased risk for CVD [4].

The main abnormalities of lipid metabolism are high TC, high TG, high LDL, low HDL and atherogenic dyslipidaemia. Atherogenic dyslipidaemia manifests itself by low HDL, elevated TGL, raised apolipoprotein B, increased remnant lipoproteins, small HDL and small LDL particles [2] [5]. Atherogenic dyslipidaemia is often seen in the metabolic syndrome and is also common in type $2 \mathrm{DM}$ where TC and LDL levels are similar to those without DM. However in DM there is abnormal post-prandial hyperlipidaemia and LDL particles are dense and small and in addition there is accumulation of cholesterol-rich remnant particles. All these factors are associated with increased atherogenicity [2] [6].

There have been very few CVD studies in The Gambia and the only published study on lipids to date is a 1996-97 community study conducted in Banjul and Farafenni. The prevalence of high TC was $21.1 \%$ in urban Banjul and 6.1\% in rural Farafenni while the prevalence of high TG was 2.2\% and 2.9\% in Banjul and Farafenni respectively. The mean TC was $4.4(1.2) \mathrm{mmol} / \mathrm{L}$ for the urban participants and $3.8(0.9) \mathrm{mmol} / \mathrm{L}$ for the rural participants while the mean TG was $0.68(0.42) \mathrm{mmol} / \mathrm{L}$ and $0.78(0.37) \mathrm{mmol} / \mathrm{L}$ for the urban and rural subjects respectively. This study did not assay for HDL and therefore could not report on HDL and LDL [7]-[9]. WHO's 2008 estimated prevalence of high cholesterol in The Gambia was 17.9\% in males, $21.9 \%$ in females and 19.9\% for the total population [10]. Therefore as part of our study to determine the relationship between left ventricular hypertrophy and insulin resistance we measured TC, TG, and HDL in non-hypertensive and hypertensive Gambians who were seen at outpatient clinics [11] [12]. Our main objective for this current study was to determine the mean lipid level and the prevalence of lipid disorders including atherogenic dylipidaemia among patients attending outpatient clinics in Banjul, The Gambia.

\section{Materials and Methods}

This cross sectional study was conducted at the Royal Edward Francis Small Teaching Hospital (REFSH), Banjul and Medical Research Council (MRC) Laboratories, Fajara, The Gambia from January to May 2000. Patients with systemic hypertension were recruited consecutively from the hypertension clinic of REFSH. Patients with normal blood pressure who reported with minor infectious diseases and had no cardiovascular disease or diabetes mellitus were recruited from the Gate Clinic of the MRC Laboratories as the non-hypertensives. The exclusion criteria for this study were cardiovascular disease (excluding hypertension) or labile hypertension, metabolic diseases, morbid obesity and severe inter-current illnesses.

A questionnaire was administered by a field worker using the appropriate local language and one physician undertook a physical examination of all the participants after the administration of the questionnaire. The weight of participants was measured (to the nearest $0.1 \mathrm{~kg}$ ) on electric scales (Secca ${ }^{\mathrm{r}} 770$, CMS London), with subjects wearing light clothes and without footwear and the height was measured to the nearest $0.5 \mathrm{~cm}$ with footwear and head gear or cap off, using standardised stadiometer. The hip and waist circumferences were measured to the nearest $0.5 \mathrm{~cm}$ using a plastic tape measure. The blood pressure was measured with a digital blood pressure machines (Omron ${ }^{\mathrm{r}}$ HOM-705 CP, Japan) on the left arm of participants [13]. Three readings were taken and the mean of the later two readings was used in the analysis [14].

An oral glucose tolerance test (OGTT) was performed utilising $75 \mathrm{~g}$ anhydrous glucose (BDH Chemicals Limited, Poole, England) in 300 - $350 \mathrm{ml}$ of water. The glucose level on a fasting, $30 \mathrm{~min}$ and $120 \mathrm{~min}$ samples was determined immediately upon taking the samples using a Haemocue analyser (Haemocue AB, Sweden). In addition venous blood samples were collected and analysed for TC, HDL and TG at the MRC Biochemistry Laboratory using a centrifugal biochemical analyzer (Cobas Fara, Roche, UK). The Friedwald formula was used in calculating the level of LDL [15]. 
The following definitions were adopted for this study. Hypertension was defined as systolic blood pressure $\geq$ 140 and/or diastolic blood pressure $\geq 90 \mathrm{mmHg}$ in subjects who are not taking antihypertensive medication [16]. Overall Obesity was defined as Body Mass Index (BMI) $\geq 30 \mathrm{~kg} / \mathrm{m}^{2}$ while Central Obesity or High Waist Hip Ratio (WHR) was defined as WHR $>0.9$ for males and $>0.8$ for females [17]. And diabetes mellitus as fasting venous blood glucose $\geq 7.0 \mathrm{mmol} / \mathrm{L}$ and or $2 \mathrm{~h}$ post glucose capillary whole blood $\geq 11.1 \mathrm{mmol} / \mathrm{L}$ [18]. Lipid disorders were defined as follows; high serum TC, TC $>5.0 \mathrm{mmol} / \mathrm{l}$; high serum TG, TG > $1.7 \mathrm{mmol} / \mathrm{l}$; high serum LDL was $\mathrm{LDL}>3.0 \mathrm{mmol} / \mathrm{l}$ and low serum $\mathrm{HDL}, \mathrm{HDL}<1.0 \mathrm{mmol} / \mathrm{l}$ in males and $\mathrm{HDL}<1.2 \mathrm{mmol} / \mathrm{l}$ in females. Atherogenic dyslipidaemia was defined as TG $>1.7 \mathrm{mmol} / \mathrm{l}$ and $\mathrm{HDL}<1.0 \mathrm{mmol} / \mathrm{l}$ in males or $\mathrm{HDL}<$ $1.2 \mathrm{mmol} / \mathrm{l}$ in females [19].

Data analysis was carried out using Microsoft Excel 2007 and Stata version 8.0 statistical package. Percentages were calculated for discrete variables and these were compared using Pearson Chi-square test. The mean and standard deviation were calculated for continuous variables, and were compared using the Student t-test. The participants were further classified into hypertensives with and without DM and normotensives with and without DM and these four subgroups were labelled as the clinical group. Univariate and multivariate logistic regression analysis were carried out with high TC, high TG, low HDL, high LDL and atherogenic dyslipidaemia as the independent outcome variables and sex, age, DM and HPT were used as the dependent variables. P-values of less than 0.05 were taken as statistically significant.

All the participants after careful consideration and explanation gave a formal consent by signing or thumb printing an informed consent form. The study was approved by The Gambia Government/MRC Ethical Committee.

\section{Results}

One hundred and eight consecutive normotensive patients (69 females) and 208 patients (138 females) with systemic hypertension on treatment were enrolled from outpatient clinics for our initial study [11] [12]. Three hundred and five participants (199 HPT, 199 females) out of the 316 with complete lipid results were included in this analysis.

The mean (standard deviation (sd)) age of the participants was 53.5 (12.0) years (Table 1). Smoking was significantly common in the males while obesity (central and general), mean BMI, WC and HC were higher in the females. The other characteristics including the proportion with DM and HPT were similar in the two sexes.

Mean TC was 4.92 (1.78) mean TG 0.94 (0.56), mean HDL 1.28 (0.48) and mean LDL was 3.20 (1.41) (Table 2). Mean HDL was significantly higher in the females than in the males. The sex differences in TC, TG and LDL were not statistically significant. The mean TG was significantly higher in the DM and DM-HPT groups than the controls and HPT only groups (Table 3). Mean TC and mean LDL were lower in the control and DM only groups compared to the HPT and DM-HPT groups though these were not statistically significant. Mean HDL was similar in all the clinical groups.

Prevalence of high TC was 41\%, high TG 9\%, low HDL 36\%, high LDL 49\% and atherogenic dyslipidaemia was $6 \%$. There were no statistically significant sex differences in the prevalence of high TC, high TG and atherogenic dyslipidaemia. The prevalence of high LDL was significantly higher in the females compared to the males while that of low HDL was similar but not up to statistical significance (Table 4). Table 5 shows the prevalence of lipid disorders by clinical group. There were no statistically significant difference in the prevalence of these disorders in the different groups, however the prevalence tend to be higher in the DM and DM-HPT groups. The exception was in atherogenic dyslipidaemia where the prevalence in the normal and HPT groups were higher. It is also worth noting that of the 46 previously undiagnosed DM patients found in this study only 3 had atherogenic dyslipidaemia and all the 3 were hypertensive as well.

High TC was in univariate logistic regression analysis associated with HPT but after adjusting for age, sex and DM this association was not up to statistical significance (Table 6). High TG was associated with only DM in both univariate and multivariate analysis. High LDL, low HDL and atherogenic dyslipidaemia were all not associated with DM and HPT in both univariate and multivariate analysis.

\section{Discussion}

Lipid disorders were very common among these outpatients in Banjul, The Gambia. The serum lipid levels of these participants were also high. The prevalence of high TC was 41\%, high TG 9\%, low HDL 36\%, high LDL 
Table 1. Characteristics of participants by sex.

\begin{tabular}{|c|c|c|c|c|}
\hline & Male & Female & All & $\mathbf{P}$ \\
\hline & Number (\%) & Number (\%) & Number (\%) & $\chi^{2}$ test \\
\hline & $106(34.8)$ & $199(65.2)$ & 305 & \\
\hline Age range (years) & $31-80$ & $27-99$ & $27-99$ & \\
\hline Smoking & 57 (53.8) & $14(7.0)$ & $71(23.3)$ & $<0.001$ \\
\hline $\mathrm{BMI} \geq 30$ & $11(10.7)$ & 67 (33.8) & 78 (25.9) & $<0.001$ \\
\hline HIGH WHR & 41 (39.8) & $175(88.4)$ & $216(71.8)$ & $<0.001$ \\
\hline HPT & 67 (63.2) & $132(66.3)$ & 199 (65.3) & 0.59 \\
\hline \multirow[t]{2}{*}{ DM } & $13(12.3)$ & 33 (16.6) & $46(15.1)$ & 0.32 \\
\hline & Mean (SD) & Mean (SD) & Mean (SD) & t test \\
\hline Age (years) & 54.7 (10.6) & $52.9(12.6)$ & $53.5(12.0)$ & 0.23 \\
\hline Weight (kg) & $69.8(15.5)$ & 71.5 (15.7) & $70.9(15.6)$ & 0.35 \\
\hline Height (m) & $1.7(0.1)$ & $1.6(0.1)$ & $1.6(0.1)$ & $<0.001$ \\
\hline $\operatorname{BMI}\left(\mathrm{kg} / \mathrm{m}^{2}\right)$ & $24.1(5.4)$ & $27.7(6.0)$ & $26.5(6.1)$ & $<0.001$ \\
\hline WC (cm) & 88.2 (12.9) & $95.0(12.1)$ & $92.7(12.8)$ & $<0.001$ \\
\hline $\mathrm{HC}(\mathrm{cm})$ & 99.4 (11.1) & $108.7(12.2)$ & 105.5 (12.6) & $<0.001$ \\
\hline Waist-Hip ratio & $0.9(0.1)$ & $0.9(0.1)$ & $0.9(0.1)$ & 0.15 \\
\hline SBP (mmHg) & 140.1 (28.5) & 136.1 (28.6) & 137.5 (28.6) & 0.24 \\
\hline DBP (mmHg) & $82.9(15.6)$ & $83.6(14.4)$ & $83.4(14.8)$ & 0.70 \\
\hline FBG $(\mathrm{mmol} / \mathrm{L})$ & $5.9(3.2)$ & $5.6(1.8)$ & $5.7(2.4)$ & 0.29 \\
\hline
\end{tabular}

Table 2. Mean serum lipids by sex.

\begin{tabular}{rcccc}
\hline & Male & Female & All & P \\
\cline { 2 - 5 } & Mean (SD) & Mean (SD) & Mean (SD) & 305 \\
\hline Number (\%) & $106(34.8)$ & $199(65.2)$ & $4.92(1.78)$ & 0.26 \\
TC (mmol/L) & $4.76(1.78)$ & $5.00(1.79)$ & $0.94(0.56)$ & 0.54 \\
TG (mmol/L) & $0.97(0.54)$ & $0.93(0.58)$ & $1.28(0.48)$ & 0.05 \\
HDL (mmol/L) & $1.21(0.46)$ & $1.32(0.49)$ & $3.20(1.41)$ & 0.39 \\
LDL (mmol/L) & $3.11(1.43)$ & $3.25(1.39)$ &
\end{tabular}

Table 3. Mean serum lipids by clinical group.

\begin{tabular}{|c|c|c|c|c|c|c|}
\hline & Control & HPT & DM & DM-HPT & All & $\mathbf{P}$ \\
\hline & Mean (SD) & Mean (SD) & Mean (SD) & Mean (SD) & Mean (SD) & F test \\
\hline Number (\%) & 98 (32.1) & $161(52.8)$ & $8(2.6)$ & 38 (12.5) & 305 & \\
\hline TC (mmol/L) & $4.56(1.22)$ & 5.05 (1.93) & $4.88(1.54)$ & $5.27(2.26)$ & $4.92(1.78)$ & 0.10 \\
\hline TG (mmol/L) & $0.81(0.51)$ & $0.97(0.48)$ & $1.40(1.00)$ & $1.12(0.78)$ & $0.94(0.56)$ & $<0.01$ \\
\hline HDL $(\mathrm{mmol} / \mathrm{L})$ & $1.26(0.36)$ & $1.29(0.53)$ & $1.26(0.31)$ & $1.31(0.58)$ & $1.28(0.48)$ & 0.94 \\
\hline $\mathrm{LDL}(\mathrm{mmol} / \mathrm{L})$ & $2.94(1.02)$ & 3.32 (1.52) & 2.97 (1.03) & 3.45 (1.75) & $3.20(1.41)$ & 0.11 \\
\hline
\end{tabular}


Table 4. Prevalence of lipid disorders by sex.

\begin{tabular}{ccccc}
\hline & Male & Female & All & P \\
\cline { 2 - 5 } & Number (\%) & Number (\%) & Number (\%) & $\chi^{2}$ test \\
\hline Number (\%) & $106(34.8)$ & $199(65.2)$ & 305 & 0.40 \\
High TC & $40(37.7)$ & $85(42.7)$ & $125(41.0)$ & 0.15 \\
High TG & $6(5.7)$ & $21(10.6)$ & $27(8.9)$ & 0.06 \\
Low HDL & $31(29.3)$ & $80(40.2)$ & $111(36.4)$ & 0.03 \\
High LDL & $43(40.6)$ & $107(53.8)$ & $150(49.2)$ & 0.90 \\
Dyslipidaemia & $6(5.7)$ & $12(6.0)$ & $18(5.9)$ & \\
\hline
\end{tabular}

Table 5. Prevalence of lipid disorders by clinical group.

\begin{tabular}{ccccccc}
\hline & Control & HPT & DM & DM-HPT & All & P \\
\cline { 2 - 7 } & Number (\%) & Number (\%) & Number (\%) & Number (\%) & Number (\%) & $\chi^{2}$ test \\
\hline Number (\%) & $98(32.1)$ & $161(52.8)$ & $8(2.6)$ & $38(12.5)$ & 305 & \\
High TC & $32(32.7))$ & $71(44.1)$ & $3(37.5)$ & $19(50.0)$ & $125(41.0)$ & 0.19 \\
High TG & $7(7.1)$ & $12(7.5)$ & $2(25.0)$ & $6(15.8)$ & $27(8.9)$ & 0.13 \\
Low HDL & $31(31.6)$ & $60(37.3)$ & $4(50.0)$ & $16(42.1)$ & $111(36.4)$ & 0.53 \\
High LDL & $44(44.9)$ & $81(50.3)$ & $4(50.0)$ & $21(55.3)$ & $150(49.2)$ & 0.71 \\
Dyslipidaemia & $6(6.1)$ & $9(5.6)$ & $0(0)$ & $3(1.9)$ & $18(5.9)$ & 0.85 \\
\hline
\end{tabular}

Table 6. Univariate and multivariate logistic regression analysis with high TC, high TG, low HDL, high LDL and dyslipidaemia as the outcome variable.

\begin{tabular}{|c|c|c|c|c|c|c|}
\hline & \multicolumn{3}{|c|}{ Univariate } & \multicolumn{3}{|c|}{ Multivariate } \\
\hline & OR & CI & $\mathbf{P}$ & OR & CI & $\mathbf{P}$ \\
\hline \multicolumn{7}{|c|}{ High TC } \\
\hline Age & 1.00 & $0.98-1.02$ & 0.88 & 1.00 & $0.98-1.02$ & 0.85 \\
\hline Sex & 1.23 & $0.76-1.99$ & 0.40 & 1.20 & $0.74-1.95$ & 0.47 \\
\hline HPT & 1.67 & $1.02-2.74$ & 0.04 & 1.64 & $1.00-2.72$ & 0.06 \\
\hline DM & 1.39 & $0.74-2.61$ & 0.31 & 1.25 & $0.66-2.37$ & 0.50 \\
\hline \multicolumn{7}{|c|}{ High TG } \\
\hline Age & 1.02 & $0.99-1.06$ & 0.18 & 1.02 & $0.99-1.06$ & 0.16 \\
\hline Sex & 1.97 & $0.77-5.03$ & 0.16 & 1.95 & $0.75-5.05$ & 0.17 \\
\hline HPT & 1.07 & $0.46-2.48$ & 0.87 & 0.81 & $0.34-1.96$ & 0.64 \\
\hline DM & 2.66 & $1.09-6.50$ & 0.03 & 2.60 & $1.03-6.54$ & 0.04 \\
\hline \multicolumn{7}{|c|}{ High LDL } \\
\hline Age & 1.01 & $0.99-1.03$ & 0.53 & 1.01 & $0.99-1.03$ & 0.54 \\
\hline Sex & 1.70 & $1.06-2.75$ & 0.03 & 1.70 & $1.05-2.76$ & 0.03 \\
\hline HPT & 1.27 & $0.79-2.04$ & 0.32 & 1.20 & $0.73-1.95$ & 0.47 \\
\hline $\mathrm{DM}$ & 1.8 & $0.68-2.39$ & 0.45 & 1.17 & $0.62-2.23$ & 0.63 \\
\hline \multicolumn{7}{|c|}{ Low HDL } \\
\hline Age & 1.02 & $1.00-1.04$ & 0.13 & 1.02 & $1.00-1.04$ & 0.13 \\
\hline Sex & 1.63 & $0.98-2.70$ & 0.06 & 1.65 & $0.99-2.75$ & 0.05 \\
\hline $\mathrm{HPT}$ & 1.25 & $0.76-2.06$ & 0.37 & 1.12 & $0.67-1.87$ & 0.68 \\
\hline $\mathrm{DM}$ & 1.42 & $0.75-2.68$ & 0.28 & 1.31 & $0.68-2.52$ & 0.41 \\
\hline \multicolumn{7}{|c|}{ Dyslipidaemia } \\
\hline Age & 1.02 & $0.98-1.06$ & 0.37 & 1.02 & $0.98-1.06$ & 0.37 \\
\hline Sex & 1.07 & $0.39-2.93$ & 0.90 & 1.09 & $0.40-3.01$ & 0.87 \\
\hline HPT & 1.07 & $0.39-2.94$ & 0.90 & 0.97 & $0.34-2.74$ & 0.96 \\
\hline DM & 1.13 & $0.32-4.09$ & 0.85 & 1.11 & $0.0-4.07$ & 0.88 \\
\hline
\end{tabular}


$49 \%$ and atherogenic dyslipidaemia was $6 \%$. These prevalence rates are comparatively very high particularly that of high TC and high LDL.

These rates are higher compared to the previous community study by van der Sande et al. They reported an overall prevalence of $21 \%$ for high TC for urban Banjul, $13 \%$ in males and $29 \%$ in females, and total prevalence of $6 \%$ for rural Farafenni, $2 \%$ in men and $8 \%$ in women [7]. Our study found a prevalence of high TC of 38\% for male and $43 \%$ for women and these were participants mainly from Banjul. Comparing with the Banjul pariticipants from the previous study our prevalence rates were still high. van der Sande et al. also reported the following prevalence rates for high TC in their hypertensive population, total 32\%, 25\% in men, 39\% in women for urban participants and total of $10 \%, 4 \%$ in men and $14 \%$ in women for the rural participants [7]. Our prevalence rates of $44 \%$ HPT and 50\% in DM-HPT were still higher.

The previous community study also reported on high TG prevalence rates. The total prevalence was $2 \%, 4 \%$ in men and $1 \%$ in women for the urban participants and a total of $3 \%, 4 \%$ in male and $2 \%$ in females for the rural participants. They also reported $4 \%$ for men, $5 \%$ for women, $4 \%$ total for urban hypertensives and $1 \%$ for men, $3 \%$ for women and $2 \%$ total prevalence for rural hypertensives [7]. These results were lower than our findings of $9 \%$ total prevalence, $6 \%$ in males, $11 \%$ in females, $8 \%$ in HPT only and $16 \%$ in DM-HPT. These findings can be explained by the fact that the participants in our study were hospital attendants compared to the previous study where the participants were recruited from the community.

Other hospital based studies have shown high prevalence of lipid abnormalities among patients. Idogun et al. found a dyslipidaemia prevalence of $25 \%$ - $69 \%$ among diabetics with and without complications reporting to the teaching hospital in Benin City, Nigeria [20]. Eghan and Acheampong reported prevalence of high TC of $45 \%$, high TG of $26 \%$, low HDL of $31 \%$ and high LDL of $72 \%$ while Micah and Nkum reported a prevalence of 54\% for high TC, 32\% for high TG, 14\% for low HDL and 72\% for high LDL for DM and HPT patients from the same tertiary hospital in Kumasi, Ghana [21] [22].

These high prevalence rates of lipid disorders certainly predisposes to an increased risk of CVD such as coronary artery disease, stroke and peripheral vascular disease among these Gambian hospital patients particularly those with HPT, DM and DM-HPT. However the prevalence of atherogenic dyslipidaemia, 6\%, was not as high as that of the other lipid disorders. And among the 46 previously undiagnosed DM found in this study only 3 had this type of dyslipidaemia which is supposed to be very common among DM and all the 3 patients had HPT as well. In the Botnia Study, DM patients had a prevalence of atherogenic dyslipidaemia three times higher than those with normal glucose tolerance [23].

The mean TC was $4.92(1.78) \mathrm{mmol} / \mathrm{L}$, mean TG was $0.94(0.56) \mathrm{mmol} / \mathrm{L}$, mean HDL was $1.28(0.48)$ $\mathrm{mmol} / \mathrm{L}$ and mean LDL $3.20(1.41) \mathrm{mmol} / \mathrm{L}$. These levels were high especially that of LDL which was higher than the cut off for high LDL. The previous Gambian study had reported lower lipid levels compared to the current findings. It reported a mean TC of $4.1(1.1) \mathrm{mmol} / \mathrm{L}$ for urban men, $4.6(1.2) \mathrm{mmol} / \mathrm{L}$ for urban women, 3.6 $(0.9) \mathrm{mmol} / \mathrm{L}$ for rural men and $3.9(0.9)$ for rural women. The mean TG were as follows $0.68(0.39), 0.68(0.44)$, $0.81(0.37)$ and $0.76(0.37)$ for urban men, urban women, rural men and rural women respectively. The results for the hypertensives from the urban Banjul were rather similar to the findings from our study. They reported mean TC of $4.9(1.1) \mathrm{mmol} / \mathrm{L}$ for men and $5.0(1.2) \mathrm{mmol} / \mathrm{L}$ for women and mean TG of $1.13(0.43) \mathrm{mmol} / \mathrm{L}$ for males and $0.79(0.42)$ for females in the hypertensives [7]. These figures compares with our findings of 4.76 (1.78) $\mathrm{mmol} / \mathrm{L}$ and $5.00(1.79) \mathrm{mmol} / \mathrm{L}$ for mean TC in male and female respectively and mean TG of $0.97(0.54)$ $\mathrm{mmol} / \mathrm{L}$ in males $0.93(0.58) \mathrm{mmol} / \mathrm{L}$ in females.

Similar results of high lipid levels have been reported from hospital based studies on DM and HPT patients from Accra and Kumasi, Ghana and Nigeria [20]-[22] [24]. Micah and Nkum reported 5.32 (1.24) mmol/L, 1.52 (0.81) $\mathrm{mmol} / \mathrm{L}, 1.65(0.57) \mathrm{mmol} / \mathrm{L}$ and $3.42(1.22) \mathrm{mmol} / \mathrm{L}$ for mean TC, mean TG, mean HDL and mean LDL respectively. However in that report mean TC and LDL were significantly higher in than males but there were no sex difference in mean TG and HDL. There were significant clinical group differences for mean TC, TG and LDL but HDL was similar in the normal, DM, HPT and DM-HPT participants [22]. In this current study only mean HDL was significantly higher in the females than in the males while there were no sex differences in TC, TG and LDL. In addition mean TG was significantly higher in the DM and DM-HPT groups compared to the controls and HPT only groups but the difference in mean TC, mean LDL and mean HDL were not significant in the various clinical groups.

Logistic regression analysis revealed that in these participants there was only a weak relationship between high TC and HPT while there was a much stronger relationship between high TG and DM. DM and HPT had no 
association with high LDL, low HDL and atherogenic dyslipidaemia. In Kumasi TC was shown to be associated with SBP, TG was associated with SBP and FBG, HDL was associated with FBG while LDL was not associated with DBP, SBP nor FBG [22]. Both FBG levels and BP were not associated with lipid levels in Accra [24].

The lowest prevalence of lipid abnormalities were in all cases recorded in the normal or the group with neither DM or HPT even though this was not shown to be statistically significant. The only exception was the prevalence of atherogenic dyslipidaemia which surprisingly was highest in the normal group, a finding at variance with the results of the Botnia Study [23]. Further the lowest mean levels of lipids were also recorded in these normal participants. These findings indicates the lower risk of atherosclerosis in the participants with no DM or HPT compared to the increased risk in patients with either or both of these conditions. These results were not different from the observations in Accra, Kumasi and Nigeria [20]-[22] [24].

\section{Conclusion}

The mean lipid levels and the prevalence of lipid disorders in these hospital attendants were high. There is a need therefore for further studies, increased screening and treatment of these disorders among the Gambian patients.

\section{Acknowledgements}

This study was funded by the Medical Research Council (MRC), UK. I acknowledge that with great gratitude. I am grateful for the support of the Royal Victoria Teaching Hospital (RVTH), for the co-operation of the study participants, for the hard work of the field workers and the support from MRC Support Service. I am also grateful to Dr. Hilton Whittle, Dr. T. Corrah, Dr. S. Allen, Dr. K. McAdam and Dr. Alieu Gaye for their ideas, keen interest and help. My sincere gratitude goes to Dr. Aliu O. Akano and Mr. Winston Banya for their echocardiography and statistical assistance respectively. This study would never have materialised without the help of the Ghanaian community at the MRC, led by Mr. Ben Sam. For their brotherly love and moral support I remain grateful.

\section{References}

[1] Mackay, J. and Mensah, G.A. (2004) Atlas of Heart Diseases and Stroke. WHO.

[2] Rydén, L., Standl, E., Bartnik, M., Van den Berghe, G., Betteridge, J., de Boer, M.J., Cosentino, F., Jönsson, B., Laakso, M., Malmberg, K., Priori, S., Ostergren, J., Tuomilehto, J., Thrainsdottir, I., Vanhorebeek, I., Stramba-Badiale, M., Lindgren, P., Qiao, Q., Priori, S.G., Blanc, J.J., Budaj, A., Camm, J., Dean, V., Deckers, J., Dickstein, K., Lekakis, J., McGregor, K., Metra, M., Morais, J., Osterspey, A., Tamargo, J., Zamorano, J.L., Deckers, J.W., Bertrand, M., Charbonnel, B., Erdmann, E., Ferrannini, E., Flyvbjerg, A., Gohlke, H., Juanatey, J.R., Graham, I., Monteiro, P.F., Parhofer, K., Pyörälä, K., Raz, I., Schernthaner, G., Volpe, M. and Wood, D., Task Force on Diabetes and Cardiovascular Diseases of the European Society of Cardiology (ESC); European Association for the Study of Diabetes (EASD) (2007) Guidelines on Diabetes, Pre-Diabetes, and Cardiovascular Diseases: Executive Summary. The Task Force on Diabetes and Cardiovascular Diseases of the European Society of Cardiology (ESC) and of the European Association for the Study of Diabetes (EASD). European Heart Journal, 28, 88-136.

[3] Austin, M.A., Hokanson, J.E. and Edwards, K.L. (1996) Plasma Triglyceride Is a Risk Factor for Cardiovascular Disease Independent of High-Density Lipoprotein Cholesterol Level: A Metaanalysis of Population-Based Prospective Studies. Journal of Cardiovascular Risk, 3, 213-219.

[4] Sznajderman, M. (1996) Hypertension and Lipids. Blood Pressure. Supplement, 1, 14-17.

[5] Ginsberg, H.N. and Huang, L.S. (2000) The Insulin Resistance Syndrome: Impact on Lipoprotein Metabolism and Atherothrombosis. Journal of Cardiovascular Risk, 7, 325-331. http://dx.doi.org/10.1177/204748730000700505

[6] Lehto, S., Ronnemaa, T., Haffner, S.M., Pyörälä, K., Kallio, V. and Laakso, M. (1997) Dyslipidaemia and Hypertriglyceridaemia Predict Coronary Heart Disease Events in Middle-Aged Patients with NIDDM. Diabetes, 46, 1354-1359. http://dx.doi.org/10.2337/diab.46.8.1354

[7] van der Sande, M.A., Milligan, P.J., Nyan, O.A., Rowley, J.T., Banya, W.A., Ceesay, S.M., Dolmans, W.M., Thien, T., McAdam, K.P. and Walraven, G.E. (2000) Blood Pressure Patterns and Cardiovascular Risk Factors in Rural and Urban Gambian Communities. Journal of Human Hypertension, 14, 489-496. http://dx.doi.org/10.1038/sj.jhh.1001050

[8] van der Sande, M.A., Ceesay, S.M., Milligan, P.J., Nyan, O.A., Banya, W.A., Prentice, A., McAdam, K.P. and Walraven, G.E. (2001) Obesity and Undernutrition and Cardiovascular Risk Factors in Rural and Urban Gambian Communities. American Journal of Public Health, 91, 1641-1644. http://dx.doi.org/10.2105/AJPH.91.10.1641 
[9] van der Sande, M.A., Walraven, G.E., Milligan, P.J., Banya, W.A., Ceesay, S.M., Nyan, O.A. and McAdam, K.P. (2001) Family History: An Opportunity for Early Interventions and Improved Control of Hypertension, Obesity and Diabetes. Bulletin of the World Health Organization, 79, 321-328.

[10] Noncommunicable Diseases, Gambia, World Health Organisation. http://www.who.int/nmh/countries/gmb_en.pdf

[11] Nkum, B.C., Nyan, O., Corrah, T., Ankrah, T.C., Allen, S., Micah, F.B. and McAdam, K.P. (2009) Resting Electrocardiographic and Echocardiographic Findings in an Urban Community in the Gambia. Journal of Science and Technology, 29, 130-140.

[12] Nkum, B.C., Micah, F.B., Ankrah, T.C. and Nyan, O. (2014) Left Ventricular Hypertrophy and Insulin Resistance in Adults from an Urban Community in the Gambia: Cross-Sectional Study. PLoS ONE, 9, e93606. http://dx.doi.org/10.1371/journal.pone.0093606

[13] Hammond, I.W., Devereux, R.B., Alderman, M.H., Lutas, E.M., Spitzer, M.C., Crowley, J.S. and Laragh, J.H. (1986) The Prevalence and Correlates of Echocardiographic Left Ventricular Hypertrophy among Employed Patients with Uncomplicated Hypertension. Journal of the American College of Cardiology, 7, 639-650. http://dx.doi.org/10.1016/S0735-1097(86)80476-4

[14] Mayet, J., Shahi, M., Foale, R.A., Poulter, N.R., Sever, P.S. and McG Thom, S.A. (1994) Racial Differences in Cardiac Structure and Function in Essential Hypertension. BMJ, 308, 1011-1014. http://dx.doi.org/10.1136/bmj.308.6935.1011

[15] Friedwald, W.I., Levy, R.I. and Fredrickson, D.S. (1972) Estimation of the Concentration of Low Density Lipoprotein Cholesterol in Plasma, without Use of the Preparative Ultracentrifuge. Clinical Chemistry, 18, 499-502.

[16] Chalmers, J., MacMahon, S., Mancia, G., Whitworth, J., Beilin, L., Hansson, L., Neal, B., Rodgers, A., Ni Mhurchu, C. and Clark, T. (1999) 1999 World Health Organization-International Society of Hypertension Guidelines for the Management of Hypertension. Guidelines Sub-Committee of the World Health Organization. Clinical and Experimental Hypertension, 21, 1009-1060. http://dx.doi.org/10.3109/10641969909061028

[17] National Institutes of Health (1998) Clinical Guidelines on the Identification, Evaluation, and Treatment of Overweight and Obesity in Adults—The Evidence Report. Obesity Research, 6, 51S-209S.

[18] Alberti, K.G. and Zimmet, P.Z. (1998) Definition, Diagnosis and Classification of Diabetes Mellitus and Its Complications. Part 1: Diagnosis and Classification of Diabetes Mellitus Provisional Report of a WHO Consultation. Diabetic Medicine, 15, 539-553. http://dx.doi.org/10.1002/(SICI)1096-9136(199807)15:7<539::AID-DIA668>3.0.CO;2-S

[19] De Backer, G., Ambrosioni, E., Borch-Johnsen, K., Brotons, C., Cifkova, R., Dallongeville, J., Ebrahim, S., Faergeman, O., Graham, I., Mancia, G., Manger Cats, V., Orth-Gomér, K., Perk, J., Pyörälä, K., Rodicio, J.L., Sans, S., Sansoy, V., Sechtem, U., Silber, S., Thomsen, T. and Wood, D. (2003) Third Joint Task Force of European and Other Societies on Cardiovascular Disease Prevention in Clinical Practice. European Guidelines on Cardiovascular Disease Prevention in Clinical Practice. Third Joint Task Force of European and Other Societies on Cardiovascular Disease Prevention in Clinical Practice. European Heart Journal, 24, 1601-1610. http://dx.doi.org/10.1016/S0195-668X(03)00347-6

[20] Idogun, E.S., Unuigbe, E.I., Ogunro, P.S., Akinola, O.T. and Famodu, A.A. (2007) Assessment of Serum Lipids in Nigerians with Type 2 Diabetes Mellitus Complications. Pakistan Journal of Medical Sciences, 23, 708-712.

[21] Eghan Jr., B.A. and Archeampongm, J.W. (2003) Dyslipidaemia in Outpatients at General Hospital in Kumasi, Ghana: Cross-Sectional Study. Croatian Medical Journal, 44, 576-578.

[22] Micah, F.B. and Nkum, B.C. (2012) Lipid Disorders in Hospital Attendants in Kumasi, Ghana. Ghana Medical Journal, 46, $14-21$.

[23] Isomaa, B., Almgren, P., Tuomi, T., Forsén, B., Lahti, K., Nissén, M., Taskinen, M.R. and Groop, L. (2001) Cardiovascular Morbidity and Mortality Associated with the Metabolic Syndrome. Diabetes Care, 24, 683-689. http://dx.doi.org/10.2337/diacare.24.4.683

[24] Nyarko, A., Adubofour, K., Ofei, F., Kpodonu, J. and Owusu, S. (1997) Serum Lipid and Lipoprotein Levels in Ghanaians with Diabetes Mellitus and Hypertension. Journal of the National Medical Association, 89, 191-196. 


\section{List of Abbreviations}

$\begin{array}{ll}\text { BMI } & \text { Body Mass Index } \\ \text { CVD } & \text { Cardiovascular Diseases } \\ \text { DBP } & \text { Diastolic Blood Pressure } \\ \text { DM } & \text { Diabetes Mellitus } \\ \text { FBG } & \text { Fasting Blood Glucose } \\ \text { HC } & \text { Hip Circumference } \\ \text { HDL } & \text { High-Density Lipoprotein Cholesterol } \\ \text { HPT } & \text { Hypertension } \\ \text { LDL } & \text { Low-Density Lipoprotein Cholesterol } \\ \text { MRC } & \text { Medical Research Council } \\ \text { OGTT } & \text { Oral Glucose Tolerance Test } \\ \text { REFSH } & \text { Royal Edward Francis Small Teaching Hospital } \\ \text { SBP } & \text { Systolic Blood Pressure } \\ \text { TC } & \text { Total Cholesterol } \\ \text { TG } & \text { Triglycerides } \\ \text { WC } & \text { Waist Circumference } \\ \text { WHR } & \text { Waist Hip Ratio }\end{array}$

\section{Questionnaire}

Resting electrocardiographic/echocardiographic_findings in adults from an urban community in The Gambia. Qustionnaire/physical examination record form.

\section{A. Demography and socio-economic factors}

\begin{tabular}{|c|c|}
\hline 1 & IDNO Surname First Name \\
\hline 2 & Date of interview \\
\hline 3 & Age in years \\
\hline 4 & Sex \\
\hline 5 & $\begin{array}{c}\text { Religion } \\
(\text { Moslem }=1 \text {, Christian }=2 \text {, Other }=3 \text { and specify No response }=9)\end{array}$ \\
\hline 6 & Married status $($ Married $=1$, Single $=2$, Divorced $=3$, Widowed $=4$, No response $=9$ ) \\
\hline 7 & Occupation \\
\hline 8 & $\begin{array}{c}\text { Highest level of education } \\
(\text { No formal education }=1 \text {, Madrassa }=2 \text {, Primary }=3 \text {, Secondary }=4 \text {, Technical }=5 \text {, University }=6 \text {, No response }=9 \text { ) }\end{array}$ \\
\hline 9 & $\begin{array}{c}\text { Address } \\
\text { Do you live permanently at the above address? }(\text { Yes }=1, \text { No }=2 \text {, No response }=9)\end{array}$ \\
\hline 10 & $\begin{array}{c}\text { Have you ever smoked tobacco? }(\text { Yes }=1 \text {, No }=2 \text {, Not Applicable }=8 \text {, No Response }=9) \\
\text { If Yes: } \\
\text { Still a smoker }=1 \text {, Stopped less than } 6 \text { months ago }=2 \text {, } \\
\text { Stopped less than } 1 \text { year ago }=3 \text {,Stopped less than } 5 \text { years ago }=4 \text {, Stopped greater than } 5 \text { years ago = } 5 \\
\text { How many years have you smoked in total? } \\
\text { How often do you smoke? (Not every day }=1,1-10 \text { times } / \text { day }=2,11-20 \text { times } / \text { day }=3 \text {, Over 20/day = 4) } \\
\text { Do you smoke: (Cigarette }=1 \text {, Pipe }=2 \text {, Snuff }=3 \text {, Other }=4 \text { ) }\end{array}$ \\
\hline 11 & $\begin{aligned} \text { Receiving treatment for hypertension? Yes }=1, \text { No }=2 \text {, Don't Know }=3,8=\text { Not applicable, } 9=\text { No Response } \\
\text { If yes, name } / \text { dosage }\end{aligned}$ \\
\hline 12 & $\begin{array}{c}\text { Receiving other medicatios? Yes }=1 \text {, No }=2 \text {, Don't Know }=3,8=\text { Not applicable, } 9=\text { No Response } \\
\text { If yes, name } / \text { dosage }\end{array}$ \\
\hline 13 & $\begin{array}{l}\text { Has the doctor ever diagnosed } 13 \mathrm{a} .=\text { Hypertension, } 13 \mathrm{~b} .=\text { Obesity, } 13 \mathrm{c} .=\text { Diabetes, } 13 \mathrm{~d} .=\text { Heart attack, } 13 \mathrm{e} .=\text { Stroke } \\
\qquad \text { Yes }=1, \text { No }=2 \text {, Don't Know }=3,8=\text { Not applicable, } 9=\text { No Response }\end{array}$ \\
\hline 14 & $\begin{array}{c}\text { Family history of } 14 \mathrm{a} .=\text { Hypertension, } 14 \mathrm{~b} .=\text { Obesity, } 14 \mathrm{c} .=\text { Diabetes, } 14 \mathrm{~d} .=\text { Heart attack, } 14 \mathrm{e} .=\text { Stroke } \\
\text { Yes }=1 \text {, No }=2 \text {, Don’t Know }=3,8=\text { Not applicable, } 9=\text { No Response }\end{array}$ \\
\hline 15 & $\begin{array}{l}\text { Do you have excessive thirst? Yes }=1 \text {, No }=2 \text {, Don't Know }=3,8=\text { Not applicable, } 9=\text { No Response } \\
\text { Do you produce a lot of urine? Yes }=1, \text { No }=2 \text {, Don't Know }=3,8=\text { Not applicable, } 9=\text { No Response }\end{array}$ \\
\hline 16 & $\begin{array}{l}\text { Have you ever experienced severe pain across the front of your chest lasting }>1 / 2 \text { hour? } \\
\text { Yes }=1 \text {, No }=2 \text {, Don't Know }=3,8=\text { Not applicable, } 9=\text { No Response }\end{array}$ \\
\hline
\end{tabular}




\section{Continued}

Discomfort in your chest Yes $=1$, No $=2$, Don't Know $=3,8=$ Not applicable, $9=$ No Response If yes, state where it occurs:

Upper sternum Yes $=1$, No $=2$, Don't Know $=3$, $8=$ Not applicable, $9=$ No Response

Lower sternum Yes $=1$, No $=2$, Don't Know $=3$, $8=$ Not applicable, $9=$ No Response

Left anterior chest Yes $=1$, No $=2$, Don't Know $=3$, $8=$ Not applicable, $9=$ No Response Other Yes $=1$, No $=2$, Don't Know $=3,8=$ Not applicable, $9=$ No Response

If other (specify)

Do you get it:

When walk at ordinary pace Yes $=1$, No $=2$, Don't Know $=3,8=$ Not applicable, $9=$ No Response What do you do when you get it while you are walking?

Stop or slow down $=1$, Carry on $=2$, Don't Know $=3,8=$ Not applicable, $9=$ No Response Is it relieved if you stand still? Yes $=1$, No $=2$, Don't Know $=3,8=$ Not applicable, $9=$ No Response If yes 1 = After less than $10 \mathrm{Min}, 2$ = More or equal 10 Min Precipitating factors:

Exertion Yes $=1$, No $=2$, Don't Know $=3$, $8=$ Not applicable, $9=$ No Response Emotion Yes $=1$, No = 2, Don't Know = 3, $8=$ Not applicable, $9=$ No Response Cold weather Yes $=1$, No $=2$, Don't Know $=3$, $8=$ Not applicable, $9=$ No Response If other yes, specify

Do you get pain in your leg Yes $=1$, No $=2$, Don't Know $=3,8=$ Not applicable, $9=$ No Response If yes, specify where

Calf pain Yes $=1$, No $=2$, Don’t Know $=3,8=$ Not applicable, $9=$ No Response If calf pain, does this pain occur when:

Either standing or sitting? Yes $=1$, No $=2$, Don't Know $=3,8=$ Not applicable, $9=$ No Response Hurrying or walking uphill? Yes $=1$, No $=2$, Don’t Know = 3, $8=$ Not applicable, $9=$ No Response Walking at ordinary pace Yes $=1$, No $=2$, Don't Know $=3,8=$ Not applicable, $9=$ No Response

Does the pain ever disappear while you are walking? Yes $=1$, No $=2$, Don't Know $=3,8=$ Not applicable, $9=$ No Response What do you do if you get it while you are walking?

Stop or slow down $=1$, Carry on $=2$, Don't Know $=3,8=$ Not applicable, $9=$ No Response

Is it relieved when you stand still? Yes $=1$, No $=2$, Don't Know $=3,8=$ Not applicable, $9=$ No Response

If yes, After less than $10 \mathrm{Min}=1$, More than or equal 10 Min = 2, Don't Know = 3, $8=$ Not applicable, $9=$ No Response

When hurrying on level ground or walking up a slight hill? Yes $=1$, No $=2$, Don't Know = 3, 8 = Not applicable, 9 = No Response

When walking with other people of your own age on level ground Yes $=1$, No $=2$, Don't Know = 3, 8 = Not applicable, $9=$ No Response

Do you have to stop for breath when walking at your pace on level ground?

Yes $=1$, No $=2$, Don't Know $=3,8=$ Not applicable, $9=$ No Response

Are you short of breath on washing or dressing? Yes $=1$, No $=2$, Don't Know $=3,8=$ Not applicable, $9=$ No Response

\section{B. Physical examination}

1

\section{Weight (kg) \\ Height (m)}

Waist circumference $(\mathrm{cm})$

Hip circumference $(\mathrm{cm})$

Cyanosis Yes $=1$, No $=2$

Icterus Yes $=1$, No $=2$

Digital clubbing present $\mathrm{Yes}=1$, No $=2$

If yes, state grade

Peripheral oedema Yes $=1$, No $=2$

Pulse rate (beats/min)

Pulse rhythm 1 = Regular, 2 = Regular + frequent ectopics, 3 = Regular + frequent ectopics, $4=$ Regular + irregular, 5 = Irregular + irregular, $6=$ Other If other, specify

Pulse volume 1 = Small, 2 = Moderate, 3 = Large

Arterial wall texture 1 = Normal, 2 = Hard/tortuous, $3=$ Not felt

Locomotor brachialis palpable? Yes $=1$, No $=2$

Volume of main peripheral pulses. 1 = Normal, 2 = Reduced, $3=$ Absent, 4 = Increased

Symmetry of main peripheral pulses $1=$ Equal, 2 = Unequal 


\section{Continued}

10

Arcus senilis Yes $=1$, No $=2$

BP (Systolic/diastolic, mmHg)

SBP1

DBP1

11

SBP2

DBP2

SBP3

DBP3

JVP

JVP Normal Yes $=1$, No $=2$

JVP Height (cm)

12

a wave form Normal $=1$, Absent $=2$, Large $=3$

$\mathrm{v}$ wave form Normal $=1$, Giant $=2$

Apical impulses:

Character of apical impulse 1 = Normal, 2 = Sustained heaving, 3 = Tapping, 4 = Heaving/diffuse (thrusting),

$5=$ Feeble, $6=$ Absent, $7=$ Other

If other, specify

13

Location of apical impulse 1 = Normal, 2 = Ant. Axillary line, $3=$ Axilla, 4 = Other

If other, specify

Specify interspace

Heart rate (beats/Min)

Heart rhythm 1 = Regular, 2 = Occasional premature beats, 3 = Frequent premature beats,

4 = Atrial fibrillation, 5 = Gallop, $6=$ Other

16

If other, specify heart rhythm

Heart sounds $1=$ Normal, 2 = Distant, $3=$ Not heard, $4=$ Abnormal

A2 1 = Normal, 2 = Accentuated, 3 = Diminished/absent

17

P2 1 = Normal, 2 = Accentuated, 3 = Diminished/absent

M1 1 = Normal, 2 = Accentuated, $3=$ Diminished/absent

Other Yes $=1$, No $=2$

If other is yes, specify other

Murmurs/thrills

None Yes $=1$, No $=2$

Aortic systolic Yes $=1$, No $=2$

18

Apical systolic Yes $=1$, No $=2$

Pulm systolic Yes $=1$, No $=2$

Aortic diastolic Yes $=1$, No $=2$

Apical diastolic Yes $=1$, No $=2$

Pulm diastolic Yes $=1$, No $=2$

Other specify

19

Respiratory findings:

Normal respiratory finding? Yes $=1$, No $=2$

If no, specify abnormality

20

Abdomen

Normal Yes $=1$, No $=2$

Specify if no

Attending diagnosis? Yes $=1$, No $=2$

Specify if yes

Restting electrocardiographic/echocardiographic-findings in adults from rural and urban communities in The Gambia.

Ecg Findings Record Form. 


\begin{tabular}{|c|c|}
\hline 1 & IDNO \\
\hline 2 & Rate (/min) \\
\hline 3 & $\begin{array}{l}\text { Rhythm (Sinus = 1, Abnormal = 2) } \\
\text { Specify abnormality rhythm }\end{array}$ \\
\hline 4 & Axis Normal $=1, \mathrm{LAD}=2, \mathrm{RAD}=3$, Indeterminate $=4$, Extreme $\mathrm{RAD}=5$ \\
\hline 5 & $\begin{array}{c}\text { Conduction abnormalities? Yes }=1, \text { No }=2 \\
\text { If yes, specify }\end{array}$ \\
\hline 6 & Minnesota coding \\
\hline 7 & SV1 + RV5 OR RV6 = \\
\hline 8 & $\begin{array}{l}\text { R1 AMPLITUDE } \\
\text { SV1 AMPLITUDE } \\
\text { SV2 AMPLITUDE } \\
\text { RV5 AMPLITUDE } \\
\text { SV6 AMPLITUDE } \\
\text { RAVL AMPLITUDE }\end{array}$ \\
\hline 9 & $\begin{array}{c}\text { ST-T changes Yes }=1, \text { No }=2 \\
\text { If yes, specify change } \\
\text { Specify leads involved: } \\
\text { V1V2V3 Yes }=1, \text { No }=2 \\
\text { V2V3V4 Yes }=1 \text {, No }=2 \\
\text { V4V5V6IaVL Yes }=1, \text { No }=2 \\
\text { II, III, aVF Yes }=1, \text { No }=2 \\
\text { OTHER ST-T changes Yes }=1, \text { No }=2 \\
\text { Specify other ST-T changes }\end{array}$ \\
\hline 10 & $\begin{array}{c}\text { Pathological Q Yes }=1, \text { No }=2 \\
\text { If yes, specify leads involved: } \\
\text { V1V2V3 Yes }=1, \text { No }=2 \\
\text { V2V3V4 Yes }=1, \text { No }=2 \\
\text { V4V5V6IaVL Yes }=1, \text { No }=2 \\
\text { II, III, aVF Yes }=1, \text { No }=2 \\
\text { OTHER Pathological Q Yes }=1, \text { No }=2 \\
\text { Specify other Pathological Q }\end{array}$ \\
\hline 11 & $\begin{array}{l}\text { QT Duration } \\
\text { QTC duration }\end{array}$ \\
\hline 12 & $\begin{array}{c}\text { Other enlargements } \\
\text { RAE Yes }=1, \text { No }=2 \\
\text { LAA Yes }=1, \text { No }=2 \\
\text { RVH Yes }=1, \text { No }=2\end{array}$ \\
\hline 13 & $\begin{array}{l}\text { QRS Durations } \\
\text { V1 } \\
\text { V5 } \\
\text { V6 }\end{array}$ \\
\hline
\end{tabular}

Restting electrocardiographic/echocardiographic_findings in adults from rural and urban communities in The Gambia.

Echocardiographic Findings Record Form.

\begin{tabular}{cc}
\hline 1 & IDNO \\
2 & LEFT VENTRICULAR ENDO-DIASTOLIC DIAMETER (mm) LVEDD \\
3 & LEFT VENTRICULAR ENDO-SYSTOLIC DIAMETER (mm) LVESD \\
$4 \mathrm{a}$ & INTERVENTRICULAR SEPTAL THICKNESS IN DIASTOLE (mm) IVSTD \\
$4 \mathrm{~b}$ & INTERVENTRICULAR SEPTAL THICKNESS IN SYSTOLE $(\mathrm{mm})$ IVSTS \\
$5 \mathrm{a}$ & LEFT VENTRICULAR POSTERIOR WALL THICKNESS IN DIASTOLE (mm) LVPWTD \\
$5 \mathrm{~b}$ & LEFT VENTRICULAR POSTERIOR WALL THICKNESS IN SYSTOLE (mm) LVPWTS \\
\hline
\end{tabular}




\section{Continued}

\begin{tabular}{cc}
\hline 6 & FRACTIONAL SHORTENING (\%) FS \\
7 & EJECTION FRACTION (GIBSON) (\%) EF \\
8 & LAD TO AOD RATIO LADAOD \\
9 & EF SLOPE (mm/s) EFSLOPE \\
10 & MITRAL END-POINT SEPTAL SEPARATION (mm) MEPPS \\
\hline
\end{tabular}

Restting electrocardiographic/echocardiographic_findings in adults from rural and urban communities in the Gambia.

Biochemical results.

\begin{tabular}{lc}
\hline 1 & IDNO \\
& OGTT \\
2 & OGTT $(0 \mathrm{~min})(\mathrm{mmol} / \mathrm{l})$ \\
& OGTT $(30 \mathrm{~min})(\mathrm{mmol} / \mathrm{l})$ \\
3 & OGTT $(120 \mathrm{~min})(\mathrm{mmol} / \mathrm{l})$ \\
& Insulin level $(\mathrm{micro} \mathrm{U} / \mathrm{ml})$ \\
4 & Lipids: \\
5 & Total cholesterol $(\mathrm{mmol} / \mathrm{l})$ \\
6 & Triglycerides $(\mathrm{mmol} / \mathrm{l})$ \\
& HDL (mmol/l) \\
& Creatinine (umol/l) \\
\hline
\end{tabular}

